\begin{tabular}{l|l|l} 
Jurnal Eksplorasi Akuntansi & Vol. 1, No 4, Seri C, November 2019, Hal 1863-1880
\end{tabular} \mid $\begin{aligned} & \text { ISSN : 2656-3649 (Online) } \\
& \text { http://jea.ppj.unp.ac.id/index.php/jea/issue/view/16 }\end{aligned}$

\title{
Pengaruh Komitmen Profesional Dan Sosialisasi Antisipatif Mahasiswa Akuntansi Terhadap Niat Whistleblowing Dengan Religiusitas Sebagai Variabel Moderasi \\ (Studi Empiris pada Mahasiswa Akuntansi di Kota Padang)
}

\author{
Isfan Fajar Satrya ${ }^{1}$, Herlina Helmy ${ }^{2}$, Salma Taqwa ${ }^{3}$ \\ ${ }^{1}$ Alumni Jurusan Akuntansi Fakultas Ekonomi, Universitas Negeri Padang \\ ${ }^{2}$ Jurusan Akuntansi Fakultas Ekonomi, Universitas Negeri Padang \\ ${ }^{3}$ Jurusan Akuntansi Fakultas Ekonomi, Universitas Negeri Padang \\ *Korespondensi: isfan.fajar2305@gmail.com
}

\begin{abstract}
The accounting profession has emphasized the need for professionals to develop attitudes early in their careers, even before they moved professions. This study discusses the professional commitment and anticipatory socialization of accounting students towards whistleblowing intentions. Religiosity as a moderating variable that moderates the relationship between professional commitment and anticipatory socialization of accounting students to whistleblowing intentions. The population in this study is accounting students in the city of Padang. The sample is based on the purposive stratified sampling method. The data used in this study are primary data. This study used a questionnaire instrument from 277 respondents. The method of analysis is done by using MRA (Moderated Regression Analysis). The results showed that professional commitment had a significant effect on whistleblowing, but anticipatory socialization had a significant negative effect on whistleblowing. Religiosity weakens the relationship between professional commitment to whistleblowing but supports the relationship between anticipatory socialization of whistleblowing.
\end{abstract}

Keywords: professional commitment; socialization, antisipation; religiusity, whistleblowing.

\section{How to cite (APA $6^{\text {th }}$ style)}

Satrya, I. F., Helmy, H. \& Taqwa, S. (2019). Pengaruh Komitmen Profesional dan Sosialisasi Antisipatif Mahasiswa Akuntansi terhadap Niat Whistleblowing dengan Religiusitas sebagai Variabel Moderasi (Studi Empiris pada Mahasiswa Akuntansi di Kota Padang). Jurnal Eksplorasi Akuntansi, 1(4), Seri C, 1863-1880.

\section{PENDAHULUAN}

Profesi akuntan merupakan yang salah banyak kerjanya ialah melakukan pengecekan kepada laporan keuangan suatu perusahan, kemudian ia memberi opini terhadap saldo akun pada laporan keuangan, apa sudah disajikan dengan sewajarnya dan mengikuti standar atau prinsip yang diterapkan secara terus menerus. Untuk menjadi seorang profesional, akuntan diharapkan berperilaku sesuai etika dalam setiap pekerjaan yang dilakukan. Profesi akuntansi sebagai penyedia informasi seharusnya memberikan informasi yang terpercaya bagi para pengguna laporan keuangan. Adanya kegagalan pada penyediaan informasi yang terpercaya bagi para pengguna laporan keuangan mengakibatkan terjadinya kerugian, dikarenakan para pengguna 
laporan keuangan mendasarkan keputusannya dari informasi yang disajikan oleh profesi akuntansi tersebut.

Kasus-kasus manipulasi akuntansi yang terjadi merupakan salah satu penyebab utama timbulnya keraguan masyarakat terhadap profesionalisme profesi akuntansi. Di tahun 2002, Enron, WorldCom, dan banyak perusahaan kecil lainnya menyatakan kebangkrutan dampak dari skandal keuangan. Para eksekutif keuangan mereka dihukum karena melakukan kesalahan dalam membuat laporan. Dampak dari skandal ini, banyak klien yang menghentikan kerjasama dengan KAP Arthur Andersen sebagai auditor utama mereka, sehingga mengakibatkan KAP Arthur Andersen akhirnya bangkrut. Tindaklanjut dari skandal yang mengakibatkan kebangkrutan ini menghasilkan penerapan standar yang lebih kuat oleh Sarbanes Oxley Act (SOX) (Merdikawati \& Prastiwi, 2012).

Kasus-kasus besar yang terjadi dimasa lalu tersebut, membuat semua pembuat regulasi berusaha memperoleh kembali kepercayaan rakyat kepada akuntan. Banyak cara mencegah terjadi penyimpangan akuntansi sehingga dapat memperolah lagi kepercayaan masyarakat, salah satunya dengan melakukan whistleblowing (Merdikawati \& Prastiwi, 2012). Whistleblowing adalah pengungkapan oleh anggota organisasi (dahulu atau sekarang) praktik ilegal, tidak bermoral, atau tidak sah di bawah kendali atasan mereka, kepada orang atau organisasi yang mungkin dapat melakukan tindakan (Near and Miceli, 1985 dalam Elias, 2008). Pelapor dapat bersifat internal atau eksternal tergantung pada pihak yang menerima pengaduan.

Profesi akuntansi secara umum telah mendorong tindakan whistleblowing internal. Penelitian menunjukkan bahwa kebanyakan whistleblower pertama kali mengungkapkan temuan mereka secara internal sebelum melaporkannya ke publik (Miceli dan Near, 2002 dalam Sari, 2016). Untuk bisa menjadi seorang whistleblower antara lain harus memiliki informasi, bukti, atau indikasi yang akurat mengenai terjadinya pelanggaran yang dilaporkan dengan itikad baik bukan merupakan suatu keluhan pribadi atas suatu kebijakan perusahaan tertentu, ataupun didasari oleh kehendak buruk atau fitnah sehingga informasi yang diungkap dapat ditelusuri atau ditindak lanjuti (Semendawai, 2011).

Dalam theory of planned behavior, perilaku yang ditunjukkan seseorang muncul akibat dari intensi untuk berperilaku. Intensi individu untuk menampilkan suatu perilaku adalah kombinasi dari sikap untuk menampilkan perilaku dan norma subjektif. Sehingga, seorang individu akan melakukan tindakan whistleblowing jika memang terdapat kecurangan yang harus dilaporkan. Theory of planned behavior mengungkapkan bahwa minat ialah suatu fungsi dari adanya dua penentu dasar yang saling berhubungan dengan faktor pribadi dan pengaruh sosial (Ajzen, 1991). Niat individu untuk berperilaku dipengaruhi oleh beberapa faktor, antara lain; sikap terhadap perilaku (attitude toward the behavior), norma subyektif (subjective norm), kontrol perilaku persepsian (perceived behavioral control), niat (intention). Faktor sikap terhadap perilaku diwakili variabel komitmen profesional. Sedangkan faktor norma subyektif diwakili variabel sosialisasi antisipatif (Merdikawati \& Prastiwi, 2012).

Komitmen profesional mengacu pada keterikatan pekerja secara individu dengan berkomitmen untuk memercayai dan menerima tujuan profesi dengan berusaha lebih berkontribusi dalam mencapai tujuan dari profesi yang dijalankan. Komitmen terhadap profesi akuntansi membuat seseorang mengetahui apa yang seharusnya dilakukan, dalam hal ini whistleblowing. Komitmen profesional memiliki implikasi positif terhadap organisasi dari seseorang calon akuntan dan auditor di masa depan (Elias, 2008). Semakin kuat komitmen individu yang profesional semakin tidak ada kemungkinan ia untuk pergi meninggalkan atau mundur dari profesi yang digelutinya (Lee et al, 2000 dalam Elias, 2008). 
Sosialisasi antisipatif diartikan dengan sebuah proses pengenalan sikap dan perilaku suatu organisasi tertentu yang dilakukan oleh seseorang sebelum mereka menjadi anggota organisasi tersebut. Sosialisasi antisipatif merupakan proses longitudinal yang berkembang dari tahun ketahun pada pembelajaran ketika di universitas hingga mencapai level senior di organisasi (Elias, 2008). Penelitian Scholarios et al (2003) dalam Jalil (2014) menemukan bahwa sosialisasi antisipatif bagi profesi akuntansi memiliki pengaruh jangka panjang, hal tersebut tetap berlangsung meskipun profesi akuntansi berada dalam kecaman publik. Elias (2008) menemukan bahwa mahasiswa yang lebih berkomitmen profesi dan tersosialisasi dengan profesinya sejak dini lebih cenderung melakukan whistleblowing.

TPB menegaskan bahwa perilaku manusia berada di bawah kendali kehendaknya tanpa ada penghalang yang signifikan, memicu niat untuk berperilaku dengan cara tertentu. Nilai religious (ajaran Islam) akan membantu akuntan untuk bersikap sesuai etika, dimana ajaran agama telah menjelaskan bagaimana cara beretika yang baik. Sehingga seseorang berprofesi sebagai akuntan yang punya nilai religious tinggi dalam dirinya, maka dia akan punya rasa takut apabila dia melakukan pelanggaran terhadap perintah Tuhan atau melakukan hal dilarang agama. Sehingga etika profesi yang telah ditetapkan mampu dia jalankan dengan baik. Religiusitas juga mengajarkan kesetiaan, rasa tanggung jawab dan secara umum seperangkat nilai yang membuat individu berkomitmen terhadap pekerjaan mereka.

Religiusitas pada penilitian ini sebagai variabel moderasi. Tujuannya untuk melihat pengaruhnya terhadap hubungan Komitmen Profesional dan Sosialisasi Antisipatif mahasiswa akuntansi terhadap Whistleblowing. Hal ini didorong penelitian Kashif et al (2017) yang memasukkan religiusitas ke dalam model TPB. Penelitian ini dilakukan pada mahasiswa akuntansi strata-1 muslim atau beragama Islam di kota Padang. Indonesia merupakan negara dengan muslim terbanyak di dunia menjadi alasannya. Sumatera Barat dengan kota Padang sebagai ibu kota provinsinya mayoritas masyarakatnya pemeluk agama Islam.

Terdapat salah satu falsafah hidup masyarakat Minangkabau yang terkenal berbunyi " adaik basandi syarak, syarak basandi kitabullah", kurang lebih bermakna, adat yang didasarkan atau ditopang oleh syariat agama Islam yang syariat tersebut berdasarkan pula pada Al-Qur'an dan Hadist. Kitabullah yang dimaksud dengan ikrar diatas adalah Al-Qur'an, falsafah hidup tersebut menegaskan bahwa masyarakat Minangkabau sangat menjunjung tinggi syariat Islam. Masyarakat Minangkabau hanya mengenal agama tunggal yaitu agama Islam, apabila seseorang yang berasal dari Minangkabau pasti seseorang tersebut beragama Islam (Amir, 1997:133).

\section{REVIU LITERATUR DAN HIPOTESIS \\ Prosocial Organizational Behavior Theory}

Salah satu teori yang mendukung whistleblowing adalah prosocial organizatinal behavior theory. Brief dan Motowidlo (1986) dalam Bagustianto (2014) mendefinisikan prosocial organizational behavior sebagai suatu perilaku atau tindakan yang dilakukan oleh anggota sebuah organisasi terhadap individu, kelompok, atau organisasi yang ditujukan untuk meningkatkan kesejahteraan individu, kelompok, atau organisasi tersebut.

Menurut Dozier dan Miceli (1985) dalam Bagustianto (2014) mengungkapkan bahwa perbuatan whistleblowing dapat dinilai sebagai suatu perilaku prososial sebab secara umum perbuatan tersebut membawa manfaat bagi banyak orang (atau organisasi) selain juga bisa membawa manfaat bagi whistleblower itu sendiri. Whistleblowing sendiri dilakukan dengan tujuan demi menyelamatkan banyak orang dan juga untuk kepentingan diri whistleblower itu sendiri. Jadi, 
pihak yang melakukan whistleblowing tidak hanya mempertimbangkan kepentingan banyak orang, whistleblower juga memikirkan tentang kedudukannya sendiri dalam organisasinya.

\section{Theory of Planned Behavior (TPB)}

Theory of planned behavior bertujuan untuk memprediksi dan memahami dampak dari niat berperilaku, mengidentifikasi strategi untuk merubah perilaku serta menjelaskan perilaku nyata manusia (Ajzen, 1991). Dalam theory of planned behavior, perilaku yang diperlihatkan seorang muncul sebab adanya intensi untuk berperilaku. Intensi seseorang dalam memperlihatkan suatu tindakan ialah merupakan gabungan dari sikap untuk memperlihatkan tindakan tersebut dan norma subjektif. Sehingga seseorang akan melakukan perilaku whistleblowing apabila benar terjadi perbuatan yang mesti dilaporkan. Theory of planned behavior menjelaskan bahwa minat merupakan sebuah fungsi dari dua penentu dasar yang berhubungan dengan faktor pribadi dan pengaruh sosial (Ajzen, 1991).

\section{Whistleblowing}

Whistleblower merupakan sebutan kepada pihak atau orang yang pertama kali menyampaikan atau melaporkan suatu perbuatan atau tindakan yang melanggar aturan di tempat kerja atau orang lain berada. Dilaporkan kepada pihak internal organisasi atau kepada publik dan juga media massa atau pihak kepolisian. Pelaporan tersebut tidak serta merta dilakukan dengan itikad baik sang pelapor, namun tujuannya tidak lain untuk mengungkap kejahatan atau pelanggaran yang diketahuinya (Semendawai dkk, 2011). Definisi lain menurut Taylor \& Curtis (2010) adalah pengungkapan oleh anggota organisasi (yang masih aktif sebagai anggota ataupun yang sudah tidak menjadi anggota organisasi) atas suatu praktik-praktik ilegal, tidak bermoral, atau tanpa legitimasi dibawah kendali pimpinan kepada individu atau organisasi yang dapat menimbulkan efek tindakan perbaikan.

Whistleblowing terjadi bila ada pertentangan antara kesetiaan karyawan dan perlindungan kepentingan publik. Elias (2008) menyebutkan jika whistleblowing bisa terjadi didalam (internal) maupun diluar (eksternal). Internal whistleblowing terjadi jika ada pekerja melihat kecurangan yang dilakukan pekerja lainnya, lalu ia melaporkan kecurangan itu kepada pimpinannya. External whistleblowing terjadi jika ada seorang pegawai melihat kecurangan yang pelakunya pimpinan perusahaan, lalu ia memberitahukannya kepada publik disebabkan perbuatan itu dapat merugikan publik. Miceli dan Near (2002) dalam Elias (2008) mengatakan bahwa kebanyakan whistleblower pertama kali mengungkapkan penemuannya kepada internal perusahaan sebelum melaporkannya kepada publik.

\section{Komitmen Profesional}

Komitmen profesional merupakaan suatu kesetiaan yang ditanamkan oleh seseorang terhadap profesi yang ditekuninya, sesuatu yang dipercayainya, sesuatu yang ia terima, tujuannya dan nilainilai dari profesi yang ditekuninya (Aranya et al, 1981 dalam Elias, 2006). Ada kemauan untuk mengerahkan banyak usaha atas nama profesi dan keinginan untuk mempertahankan keanggotaan dalam profesi. Pentingnya kajian mengenai komitmen profesional karena karir seseorang merupakan bagian utama dalam hidup mereka dan komitmen profesional memiliki implikasi penting pada level individual maupun organisasional (Lee, 2000 dalam Elias, 2006).

Komitmen profesional menitik beratkan kekuatan identifikasi individu itu sendiri dengan profesi yang ia jalani. Seseorang dengan professional komitmen tinggi dan paham akan keberadaan profesinya akan berusaha sebaik mungkin dalam menjalankan tugasnya tanpa disuruh. Terdapat 
kemauan yang kuat untuk mendedikasikan profesinya demi kemanfaatan dalam organisasi tanpa mengesampingkan etika (Mela, Zarefar, dan Andreas 2016).

\section{Sosialisasi Antisipatif}

Sosialisasi antisipatif merupakan proses longitudinal yang berkembang dari tahun ketahun pada pembelajaran ketika di universitas hingga mencapai level senior di organisasi (Elias, 2008). Penelitian Scholarios et al (2003) dalam Jalil (2014) menemukan bahwa sosialisasi antisipatif bagi profesi akuntansi memiliki pengaruh jangka panjang, hal tersebut tetap berlangsung meskipun profesi akuntansi berada dalam kecaman publik. Elias (2008) menemukan bahwa mahasiswa yang lebih berkomitmen profesi dan tersosialisasi dengan profesinya sejak dini lebih cenderung melakukan whistleblowing. Proses sosialisasi antisipatif dimulai ketika mahasiswa akuntansi belajar untuk memberikan prioritas pada kebutuhan pengguna laporan keuangan (Clikeman dan Henning, 2000).

\section{Religiusitas}

Religiusitas merupakan tingkat kepercayaan yang mutlak dalam nilai-nilai agama dan cita-cita yang dijalankan dan dilaksanakan oleh seorang. Religiusitas itu sendiri ialah aspek yang telah diimani oleh individu di dalam hatinya, getaran hati nurani dan sikapnya. Hal serupa juga diungkapkan oleh Glock \& Stark, mengenai religiusitas yaitu sikap keberagamaan yang berarti adanya unsur internalisasi agama ke dalam diri seseorang (Rohayati, 2014). Religiusitas dianalogikan sebagai suatu keyakinan terhadap Tuhan (iman) dan diikuti dengan komitmen untuk menjalankan prinsip-prinsip yang dipercaya akan ketetapan Allah (Fauzan, 2014).

\section{Hubungan Komitmen Profesional dengan Whistleblowing}

Individu yang mempunyai komitmen kuat akan lebih cenderung menjalankan perbuatan baik demi menyelamatkan organisasi dari perbuatan curang. Oleh sebab itu belajar berkomitmen menjadi suatu hal yang perlu dipersiapkan oleh mahasiswa sebelum terjun ke dunia pekerjaan. Terbentuknya pemahaman mengenai nilai-nilai yang terkandung dalam sebuah profesi akan menjadikan mahasiswa lebih visioner menghadapi masa depan, menentukan apa yang mereka inginkan dan bagaimana cara untuk mencapainya.

Pengaruh komitmen profesional terhadap keputusan individu menjalankan perbuatan whistleblowing ditemukan pada penelitian (Mela, Zarefar, dan Andreas 2016) yaitu semakin kuat komitmen seseorang yang dibentuk dalam profesi mereka, membuat mereka cenderung melakukan perbuatan preventif demi menyelamatkan organisasinya, yang mencerminkan rasa kepemilikan dan tanggung jawab pada profesi mereka. Elias (2006) menemukan bahwa mahasiswa yang lebih senior memiliki level komitmen profesi yang lebih tinggi, seiring dengan meningkatnya pemahaman mereka mengenai laporan keuangan.

H2: Mahasiswa akuntansi dengan komitmen profesional cenderung memiliki niat melakukan whistleblowing

\section{Hubungan Sosialisasi Antisipatif dan Whistleblowing}

Sosialisasi antisipatif merupakan determinan yang penting dalam upaya membentuk persepsi seseorang terhadap profesinya yang ditemukan oleh Elias (2006). Beberapa literatur menyebutkan bahwa sosialisasi antisipatif memiliki pengaruh jangka panjang. Dengan itu sosialisasi antisipatif dapat membuat seseorang patuh kepada standar etika yang ada pada profesinya. Sosialisasi yang diberikan kepada mahasiswa selama dalam masa perkuliahan sebelum memasuki dunia kerja akan 
membuat mahasiswa semakin paham akan pentingnya pelaporan keuangan bagi pemakainya dan semakin menganggap whistleblowing sebagai sesuatu yang penting.

Elias (2008) menemukan jika semakin tinggi level sosialisasi antisipatif seseorang, maka kecenderungannya untuk melakukan whistleblowing akan semakin tinggi. Penelitian Clikeman dan Henning (2000) dalam Elias (2008) menyebutkan terdapat perbedaan preferensi terhadap kebutuhan pengguna laporan keuangan pada mahasiswa ketika di awal perkuliahan dan pada tahun terakhirnya. Ketika menjadi senior, mahasiswa lebih menolak manajemen laba dibandingkan saat mereka berada di tahun pertama. Dalam penelitian ini sosialisasi antisipatif diproksikan dengan persepsi pentingnya pelaporan keuangan. Berdasarkan uraian diatas maka dihipotesiskan:

H2: Mahasiswa akuntansi dengan sosialisasi antisipatif cenderung memiliki niat melakukan whistleblowing

\section{Hubungan Komitmen Profesional, Religiusitas, dan Whistleblowing}

Komitmen profesional mengacu pada keterikatan pekerja secara individu dengan berkomitmen untuk memercayai dan menerima tujuan profesi dengan berusaha lebih berkontribusi dalam mencapai tujuan dari profesi yang dijalankan (Aranya et al, 1981). Komitmen profesional memiliki implikasi positif terhadap level komitmen individu terhadap organisasi dari seseorang calon akuntan dan auditor di masa depan (Elias, 2008). Komitmen terhadap profesi akuntansi membuat seseorang mengetahui apa yang seharusnya dilakukan, dalam hal ini whistleblowing. Semakin kuat komitmen seorang akuntan maka kemungkinan mereka untuk meninggalkan profesi yang digelutinya semakin tidak mungkin (Lee et al, 2000 dalam Elias, 2008).

Religiusitas dapat memengaruhi komitmen seseorang melalui nilai-nilai agama dan moralitas. Religiusitas mengajarkan kesetiaan, rasa tanggung jawab dan secara umum seperangkat nilai yang membuat individu berkomitmen terhadap pekerjaan mereka. Adanya nilai religius sebagai pedoman hidup akan membuat seorang akuntan memiliki komitmen yang tinggi terhadap profesinya. Dengan nilai religius dan komitmen profesional seorang akuntan dalam menjalankan tugas akan sesuai dengan informasi yang didapat tanpa menambah atau mengurangi sehingga data yang diolah menjadi suatu informasi yang dapat dipertanggungjawabkan. Dengan itu membuat akuntan selalu mematuhi segala perintah yang dibenarkan oleh agama, selalu menghindari hal yang dilarang agama, juga akan mendorong niat akuntan untuk mengungkap dan melaporkan kecurangan kecurangan yang terjadi (whistleblower) di lingkungan kerjanya. Khasih et al (2017) dalam penelitiannya menemukan bahwa religiusitas memoderasi hubungan sikap terhadap perilaku dengan niat berperilaku etis. Berdasarkan uraian diatas maka dihipotesiskan:

H3: Religiusitas memperkuat komitmen profesional mahasiswa akuntansi terhadap niat melakukan whistleblowing.

\section{Sosialisasi Antisipatif, Religiusitas dan Whistleblowing}

Sosialisasi antisipatif didefinisikan sebagai proses pengadopsian sikap dan perilaku suatu kelompok tertentu yang dilakukan oleh individu sebelum mereka tergabung ke dalam kelompok tersebut. Sosialisasi antisipatif merupakan proses longitudinal yang berkembang dari tahun ketahun pada pembelajaran ketika di universitas hingga mencapai level senior di organisasi (Elias, 2008). Sosialisasi antisipatif dalam penelitian ini berperan sebagai komponen norma subyektif . Menurut Ajzen (1991) norma subyektif didefinisikan sebagai persepsi seseorang tentang bagaimana pengaruh sosial di sekitarnya dalam membentuk suatu perilaku perilaku tertentu. Apabila seorang individu terpengaruh tekanan sosial, maka perilaku seorang individu akan menunjukkan bagaimana kesepakatan sosial di lingkungannya terhadap suatu perilaku. 
Agama memiliki peran sebagai suatu sistem nilai yang memuat nilai norma-norma tertentu. Secara keseluruhan norma itu dapat menjadi kerangka acuan dalam mengambil sikap dan bertingkah laku supaya sejalan dengan aturan agama yang dianutnya. Agama yang dapat mengontrol perilaku individu untuk bersikap etis dan tidak etis. Bloodgood et al (2008) menyatakan religiusitas memiliki peran yang sangat penting dalam pembentukan komponenkomponen perilaku seseorang. Bloodgood et al (2008) menemukan tingkat religiusitas yang lebih tinggi mempengaruhi secara positif individu yang mengembangkan identitas moral yang lebih kuat, sehingga meningkatkan kemungkinan mereka membentuk niat etis yang mengarah pada pengambilan keputusan etis. Berdasarkan uraian diatas maka dihipotesiskan:

H4: Religiusitas memperkuat sosialisasi antisipatif mahasiswa akuntansi terhadap niat melakukan whistleblowing.

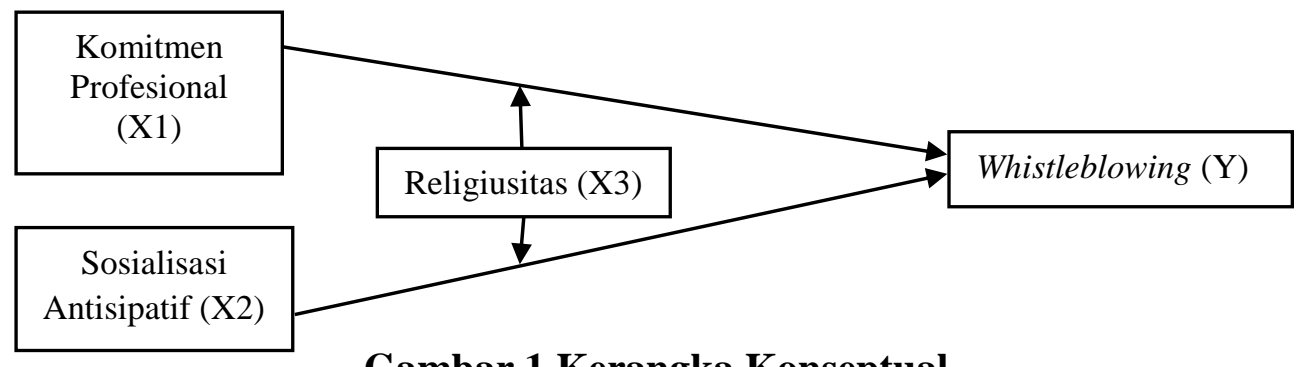

Gambar 1 Kerangka Konseptual

\section{METODE PENELITIAN \\ Jenis Penelitian}

Adapun jenis penelitian ini adalah penelitian kausatif. Menurut Sugiyono (2008:11) Penelitian kausatif bertujuan untuk menganalisis hubungan antara satu variabel dengan variabel lainnya atau bagaimana suatu variabel mempengaruhi variabel lainnya. Pada penelitian ini Pengaruh Komitmen Profesional (X1), Sosialisasi Antisipatif (X2) dan Religiusitas (X3) sebagai variabel bebas terhadap whistleblowing $(\mathrm{Y})$ sebagai variabel terikat.

\section{Populasi dan Sampel}

Populasi yang digunakan dalam penelitian ini adalah mahasiswa akuntansi di perguruan tinggi Kota Padang. Sampel yang diambil mengunakan teknik purposive stratified sampling. Dari total mahasiswa yang didapatkan dari hasil observasi maka penentuan jumlah responden pada masingmasing Universitas dilakukan perhitungan dengan menggunakan rumus Slovin (Rahmaningtyas, 2008 dalam Rani, 2008). Berdasarkan rumus tersebut dengan jumlah populasi 898 orang dan tingkat kesalahan atau presisi sebesar 5\%, maka ukuran Sampel untuk penelitian ini adalah 277 responden.

\section{Jenis Dan Teknik Pengumpulan Data}

Jenis data yang digunakan adalah data subjek. Sumber data yang digunakan adalah Data primer yaitu data penelitian yang diperoleh secara langsung dari sumber asli tanpa media perantara. Teknik pengumpulan data adalah melalui menyebarkan kuesioner kepada mahasiswa akuntansi di Kota Padang. 


\section{Instrumen Variabel Penelitian}

Pengukuran whistleblowing dalam penelitian ini menggunakan tiga skenario kasus yang dikembangkan oleh Schultz et al (1993). Schultz et al (1993) mengembangkan enam skenario kasus whistleblowing, tiga diantaranya berkaitan dengan akuntansi dan tiga lainnya bersifat umum. Serupa dengan yang dilakukan oleh Elias dalam penelitiannya, hanya skenario kasus yang berkaitan dengan akuntansi yang digunakan mempertimbangkan relevansinya dengan penelitian ini. Untuk mengukur komitmen profesional, digunakan skala yang dikembangkan oleh Dwyer et al, (2000). Dalam penelitian tersebut, penulis menganalisis skala komitmen profesional yang umum digunakan yang dikembangkan oleh Aranya et al, (1981). Aranya et al, (1981) skala terdiri dari 15 item sedangkan Dwyer et al, (2000) skala yang digunakan dalam penelitian ini terdiri dari lima item dan hanya diukur komitmen profesional afektif.

Untuk mengukur sosialisasi antisipatif, persepsi pentingnya pelaporan keuangan digunakan sebagai proxy. Clikeman dan Henning (2000) mengembangkan sebuah kuesioner untuk menentukan persepsi siswa akuntansi tentang pentingnya pelaporan keuangan. Terdapat sebelas item pernyataan yang dikembangkan oleh Clikeman dan Henning (2000) untuk mengukur tingkat sosialisasi antisipatif. Instrument religiusitas pada penelitian ini digunakan 5 Dimensi religiusitas menurut Glock \& Stark. Ancok dan Suroso (2011) berpendapat bahwa rumusan Glock \& Stark yang membagi keberagaman menjadi lima dimensi dalam tingkat tertentu mempunyai kesesuaian dengan Islam, yaitu the ideological dimension, the ritualistic dimension, the experiental dimension, the intelectual dimension, the consecuental dimension.

\section{Analisis Data \\ Uji Asumsi Klasik \\ Uji Normalitas}

Pengujian Normalitas dapat digunakan untuk menguji apakah data berdistribusi normal. Data yang baik adalah data yang mempunyai pola distribusi normal. Uji normalitas dapat dilakukan dengan metode Kolmogrov Smirnov, dengan melihat nilai signifikan pada 0,05. Jika nilai signifikan yang dihasilkan >0,05 maka berdistribusi normal.

\section{Uji Multikoliniaritas}

Sebelum melakukan analisis data dengan menggunakan MRA, maka dilakukan uji Multikoleniaritas. Multikolinearitas adalah situasi adanya korelasi variabel - variabel bebas diantara satu dengan yang lainnya, maka salah satu variabel bebas tersebut di eliminir. Untuk menguji adanya multikolienaritas, dapat dilihat memalui varians inflation factor (VIF) $<10$ dan tolerance $>0,1$.

\section{Uji Heteroskedastisitas}

Uji heterokedastisitas bertujuan untuk menguji apakah dalam model regresi terjadi ketidaksamaan varian dari residual satu pengamatan ke pengamatan yang lain (nilai errornya) Menguji ada atau tidaknya heteroskedastisitas maka penelitian ini melihat grafik scatterplots. Jika ada pola tertentu, seperti titik yang ada membentuk pola tertentu yang teratur (bergelomang, melebar kemudian menyempit), maka mengindikasi telah terjadi heteroskedasitas. Jika tidak ada pola yang jelas, serta titik menyebar di atas dan di bawah angka 0 pada sumbu Y, maka tidak terjadi heteroskedasitas. 


\section{Uji Hipotesis}

\section{Analisis Uji Interaksi Variabel Moderating}

Penelitian ini melakukan uji interaksi untuk menguji variable moderating yang berupa skeptisme profesional dengan menggunakan Moderated Regression Anlyisis (MRA). MRA merupakan aplikasi khusus moderasi, dimana dalam persamaan regresinya mengandung unsur interaksi perkalian dua atau lebih variabel independen (Ghozali,2013). Uji lnteraksi ini digunakan untuk mengetahui sejauh mana interaksi variabel religiusitas dapat mempengaruhi komitmen profesional dan sosialisasi antisipatif pada whistleblowing. Model persamaan MRA yang digunakan:

\section{$Y=a+b 1 X_{1}+b_{2} X_{2}+b_{3} X_{3}+b 4 X_{1} . X_{3}+b_{5} X_{2} . X_{3}+e$}

Dimana:

$$
\begin{aligned}
& \mathrm{Y}=\text { niat } \text { whistleblowing } \\
& \mathrm{a}=\text { Konstanta } \\
& \mathrm{b}=\text { Koefisien regresi } \\
& \mathrm{X}_{1}=\text { komitmen profesional } \\
& \mathrm{X}_{2}=\text { sosialisasi antisipatif } \\
& \mathrm{X}_{3}=\text { Religiusitas } \\
& \mathrm{e} \quad=\text { Error }
\end{aligned}
$$

\section{Pengujian Koefisien Regresi Parsial (uji T)}

Uji statistik t pada dasarnya menunjukkan seberapa jauh pengaruh satu variabel independen secara individual dalam menerangkan variasi variabel dependen (Ghozali, 2013).

Cara pengujiannya sebagai berikut:

a. Probabilitas < taraf signifikan 5\% maka H0 ditolak dan Ha diterimaartinya terdapat pengaruh signifikan antara variabel bebas secara parsial (individual) terhadap variabel terikatnya.

b. Probabilitas > taraf signifikan 5\% maka H0 diterima dan Ha ditolak artinya tidak terdapat pengaruh signifikan antara variabel bebas secara parsial (individual) terhadap variabel terikatnya.

\section{Pengujian Koefisien Regresi Simultan (Uji F)}

Uji F digunakan untuk mengetahui seberapa besar pengaruh antara variabel bebas secara bersamasama terhadap variabel terikat. Cara pengujiannya sebagai berikut:

a. Probabilitas < taraf signifikan 5\% maka $\mathrm{H} 0$ ditolak dan Ha diterima artinya terdapat pengaruh signifikan antara semua variabel bebas secara simultan/bersama terhadap variabel terikatnya.

b. Probabilitas > taraf signifikan 5\% maka H0 diterima dan Ha ditolak artinya tidak terdapat pengaruh signifikan antara semua variabel bebas secara simultan/bersama terhadap variabel terikatnya.

\section{HASIL DAN PEMBAHASAN}

Populasi pada penelitian ini yaitu mahasiswa akuntansi kota Padang dengan penyebaran kuesioner secara langsung kepada responden. Semua kuesioner yang disebar tersebut dapat diolah, kemudian diuji dan dianalisis lebih lanjut. 


\section{Uji Asumsi Klasik}

Sebelum data diolah dengan Moderated Regression Analysis maka dilakukan uij asumsi klasik untuk memperoleh keyakinan bahwa data yang diperoleh beserta variabel penelitian layak untuk diolah lebih lanjut. Uji asumsi klasik dalam penelitian ini terdiri dari:

\section{Uji Normalitas}

Tabel 1

Hasil Uji Normalitas

\begin{tabular}{|c|c|c|}
\hline \multicolumn{3}{|c|}{ One-Sample Kolmogorov-Smirnov Test } \\
\hline & & $\begin{array}{l}\text { Unstandardized } \\
\text { Residual }\end{array}$ \\
\hline $\mathrm{N}$ & & 277 \\
\hline \multirow[t]{2}{*}{ Normal Parameters ${ }^{\mathrm{a}}$} & Mean & .0000000 \\
\hline & Std. Deviation & 6.55433837 \\
\hline \multirow[t]{3}{*}{ Most Extreme Differences } & Absolute & .073 \\
\hline & Positive & .073 \\
\hline & Negative & -.073 \\
\hline Kolmogorov-Smirnov Z & & 1.223 \\
\hline Asymp. Sig. (2-tailed) & & .100 \\
\hline
\end{tabular}

Tujuan uji normalitas adalah untuk mengetahui apakah distribusi sebuah data mengikuti atau mendekati distribusi normal. Data yang baik adalah data yang mempunyai pola seperti distribusi normal. Pengujian normalitas dilakukan dengan menggunakan uji Kolmogorov Smirnov Test. Di dalam tahapan pengujian normalnya masing-masing variabel ditentukan dari nilai probability yang harus memiliki nilai di atas 0.05 . Tabel berikut memperlihatkan hasil uji normalitas menggunakan aplikasi SPSS

Berdasarkan Tabel 1 diatas terlihat bahwa hasil kolmogrov-smirnof sebesar 1.223 dengan tingkat signifikan 0.100. Dengan hasil tersebut maka dapat dinyatakan bahwa data yang digunakan dalam penelitian ini telah terdistribusi normal, karena nilai sig. (2-tailed) dari uji normalitas untuk masing-masing variabel lebih besar dari $0.05(0,100>0,05)$.

\section{Uji Multikolenearitas}

Uji terhadap multikolinearitas bertujuan untuk melihat adanya keterkaitan hubungan antara variabel bebas. Cara untuk mendeteksi adanya multikolinieritas dilakukan dengan cara meregresikan model analisis dan melakukan uji korelasi antar variabel bebas dengan menggunakan variance inflation factor (VIF) dan tolerance value. Jika nilai VIF kurang dari $10(\mathrm{VIF}<10)$ atau nilai tolerance lebih besar dari 0,10 (Tolerance $>0,10$ ) maka akan disimpulkan bahwa model tersebut tidak memiliki gejala multikolonieritas. Hasil uji multikolonieritas dapat dilihat pada tabel 
Tabel 2

Hasil Uji Multikolonearitas

\begin{tabular}{llll}
\hline \multirow{2}{*}{ Model } & \multicolumn{2}{l}{ Collinearity Statistics } \\
\cline { 3 - 4 } 1 & Tolerance & VIF \\
\cline { 2 - 4 } & Komitmen Profesional & .014 & 72.911 \\
\cline { 2 - 4 } & Sosialisasi Antisipatif & .011 & 94.972 \\
\cline { 2 - 4 } & Religiusitas & .025 & 40.447 \\
\cline { 2 - 4 } & Komitmen*Religiusitas & .006 & 165.324 \\
\cline { 2 - 4 } & Sosialisasi*Religiusitas & .003 & 299.474 \\
\hline \multicolumn{2}{l}{ Sumber : Hasil Olah Data SPSS 16.0 (2019) }
\end{tabular}

Berdasarkan tabel 2 di atas dapat dilihat variabel Komitmen Profesional dengan nilai (VIF) 72,911 dan tolerance 0,014, variabel Sosialisasi Antisipatif dengan nilai (VIF) 94,972 dengan tolerance 0,011 , dan variabel religiusitas memiliki nilai VIF 40,447 dan tolerance 0,025 , interaksi antara $\mathrm{X}_{1}$ dan $\mathrm{X}_{3}$ memiliki nilai (VIF) 165,324 dan tolerance 0,006, sedangkan untuk interaksi $\mathrm{X}_{2}$ dan $\mathrm{X}_{3}$ memiliki nilai (VIF) 299,474 dan tolerance 0,003. Dengan demikian dapat dikatakan terdapat korelasi variabel-variabel bebas antara satu dengan yang lainnya, atau variabel independen pada penelitian ini tidak bebas dari gejala multikolinearitas.

Pengujian variabel moderating dengan uji interaksi mempunyai kecenderungan akan terjadi multikolinearitas antar variabel independen (Ghozali, 2016). Regresi dengan Moderated Regression Analysis pada umumnya akan terjadi masalah multikolinearitas yang tinggi antara variabel independen, antara variabel $\mathrm{X}_{1}$ dan $\mathrm{X}_{2}$ dengan variabel moderasi $\left(\mathrm{X}_{3}\right)$.

\section{Uji Heteroskedastisitas}

Uji asumsi heteroskedastisitas adalah asumsi dalam regresi dimana varians residual tidak sama untuk satu pengamatan ke pengamatan yang lain. Cara untuk mendeteksi adanya heteroskedastisitas dapat dilakukan dengan uji Glejser. Hasil uji heteroskedastisitas dapat dilihat pada tabel 3

Tabel 3

Hasil Uji Heteroskedastisitas

\begin{tabular}{|c|c|c|c|c|c|}
\hline \multirow[b]{2}{*}{ Model } & \multicolumn{2}{|c|}{$\begin{array}{l}\text { Unstandardized } \\
\text { Coefficients }\end{array}$} & \multirow{2}{*}{$\begin{array}{l}\text { Standardized } \\
\text { Coefficients } \\
\text { Beta }\end{array}$} & \multirow[b]{2}{*}{$\mathrm{T}$} & \multirow[b]{2}{*}{ Sig. } \\
\hline & B & Std. Error & & & \\
\hline 1(Constant) & -.225 & 9.163 & & -.025 & .980 \\
\hline Komitmen Profesional & -.178 & .662 & -.130 & -.269 & .788 \\
\hline Sosialisasi Antisipatif & .378 & .392 & .535 & .965 & .335 \\
\hline Religiusitas & .155 & .134 & .417 & 1.154 & .250 \\
\hline Komitmen*Religiusitas & -.002 & .008 & -.211 & -.288 & .773 \\
\hline Sosialisasi*Religiusitas & -.004 & .005 & -.944 & -.960 & .338 \\
\hline
\end{tabular}


Pada tabel 3 dapat dilihat nilai sig untuk variabel Komitmen Profesional sebesar 0,980, untuk variabel Sosialisasi Antisipatif sebesar 0,788, untuk variabel Religiusitas 0,335, dan untuk variabel X1 * X3 sebesar 0,773 dan variabel X2 * X3 sebesar 0,338. Terlihat dari nilai signifikan masing-masing variabel bebas tersebut $>0.05$. maka dapat ditarik kesimpulan bahwa tidak terjadi heteroskedastisitas dalam penelitian ini.

\section{Uji Hipotesis}

\section{Moderated Regression Analysis}

Tabel 4: Hasil Uji Regresi Moder:

\begin{tabular}{lllll}
\hline Nama Variabel & B & Standar Error & Thitung & Sig \\
\hline (Constant) & -1.613 & 15.033 & -.107 & .915 \\
Komitmen Profesional & 6.024 & 1.086 & 5.547 & .000 \\
Sosialisasi Antisipatif & -2.036 & .642 & -3.169 & .002 \\
Religiusitas & .404 & .220 & 1.831 & .068 \\
Komitmen*Religiusitas & -.063 & .013 & -4.719 & .000 \\
\hline Sosialisasi*Religiusitas & .025 & .008 & 3.189 & .002 \\
\hline
\end{tabular}

a. Dependent Variabel: Whistle Blowing

\begin{tabular}{lc} 
Adjusted $\left(\mathbf{R}^{2}\right)$ & 0.410 \\
Fhitung & 37.592 \\
Ftabel & 2.63 \\
F Sig & 0.000 \\
\hline
\end{tabular}

Sumber : Hasil Olah Data SPSS 16.0 (2019)

Penelitian ini melakukan uji interaksi untuk menguji variabel moderating yang berupa religiusitas dengan dengan menggunakan Moderated Regression Anlyisis (MRA). MRA merupakan aplikasi khusus regresi linier berganda, dimana dalam persamaan regresinya mengandung unsur interaksi perkalian dua atau lebih variabel independen (Ghozali,2011). Perhitungan statistik dalam analisis regresi linear berganda yang digunakan dalam penelitian ini adalah dengan menggunakan bantuan program komputer SPSS 16. Berdasarkan tabel 4 di atas dapat dianalisis model persamaaan sebagai berikut:

$$
Y=1.613+6.024 X_{1}-2.036 X_{2}-0.404 X_{3}-0.063 X_{1} * X_{3}+0.025 X_{2} * X_{3}+e
$$

Keterangan:

$\mathrm{Y}=$ Whistle Blowing

$\mathrm{X}_{1}=$ Komitmen Profesional

$\mathrm{X}_{2}=$ Sosialisasi Antisipatif

$\mathrm{X}_{3}=$ Religiusitas

Berdasarkan persamaan regresi di atas dapat dijelaskan sebagai berikut

a) Konstanta $(\boldsymbol{\alpha})$ hasil uji analisis regresi moderasi terlihat bahwa nilainya sebesar 1.613 menunjukkan bahwa tanpa adanya pengaruh dari variabel bebas yaitu Komitmen Profesional, 
Sosialisasi Antisipatif dan variabel moderating Religiusitas maka Whistleblowing akan benilai sebesar 1.613.

b) Koefisien regresi ( $\beta$ ) Komitmen Profesional diperoleh sebesar 6.024 hal ini menunjukkan jika variabel komitmen profesional meningkat satu satuan maka variabel Whistleblowing akan meningkat sebesar 6.024 dengan asumsi variabel lain bernilai nol.

c) Koefisien regresi ( $\beta$ ) Sosialisasi Antisipatif diperoleh sebesar -2.036 hal ini menunjukkan jika variabel sosialisasi antisipatif meningkat satu satuan maka variabel Whistleblowing akan menurun sebesar 2.036 dengan asumsi variabel lain bernilai nol.

d) Koefisien regresi ( $\beta$ ) Religiusitas diperoleh sebesar -0.404 hal ini menunjukkan jika variabel religiusitas meningkat satu-satuan maka variabel Whistleblowing akan menurun sebesar 0.404 dengan asumsi variabel lain bernilai nol.

e) Koefisien regresi ( $\boldsymbol{\beta}) \mathbf{X}_{\mathbf{1}} * \mathbf{X}_{\mathbf{3}}$ diperoleh sebesar -0.063 , hal ini berarti setiap peningkatan religiusitas satu satuan maka akan menurunkan pengaruh variabel interaksi terhadap Whistleblowing sebesar 0.063 dengan asumsi variabel lain bernilai nol.

f) Koefisien regresi ( $\beta$ ) $\mathbf{X}_{2} * \mathbf{X}_{3}$ diperoleh sebesar 0.025 , hal ini berarti setiap peningkatan religiusitas satu satuan maka akan meningkatkan pengaruh variabel interaksi terhadap Whistleblowing sebesar 0.025 dengan asumsi variabel lain bernilai nol.

\section{Uji Kelayakan Model \\ Uji Koefisien Determinasi $\left(\mathbf{R}^{2}\right)$}

Uji ini bertujuan untuk mengukur seberapa jauh kemampuan model dalam menerangkan variasi variabel terikat. Koefisien determinasi $\left(\mathrm{R}^{2}\right)$ menunjukan proporsi yang diterangkan oleh variabel bebas dalam model terhadap variabel terikatnya, sisanya dijelaskan oleh variabel lain tidak dimasukan dalam model, formulasi model yang keliru dan kesalahan eksperimen. Pada penelitian ini hasil uji koefisien determinasi $\left(\mathrm{R}^{2}\right)$ dapat dilihat pada tabel 4.

Berdasarkan tabel 4.10 terlihat bahwa nilai $\mathrm{R}^{2}$ yang diperoleh sebesar 0.410 . Artinya variabel independen dan variabel moderasi terhadap variabel dependen sebesar $41 \% \%$. Sisanya $59 \%$ dijelaskan oleh variabel lain yang tidak dimasukan dalam penelitian ini.

\section{Uji F Statistik}

Uji F statistik pada dasarnya menunjukan apakah semua variabel bebas yang dimasukan dalam model regresi mempunyai pengaruh secara bersama-sama terhadap variabel terikat. Setelah $\mathrm{F}$ hitung regresi di temukan hasilnya kemudian dibandingkan dengan $\mathrm{F}$ tabel. Untuk menentukan nilai $\mathrm{F}$ tabel, tingkat signifikansi yang digunakan sebesar $\mathrm{a}=5 \%$ dengan derajat kebebasan $\mathrm{df}=(\mathrm{n})$.

Tabel 4 mengindikasikan bahwa nilai $\mathrm{F}$ hitung sebesar $37.592>2.64$ dengan tingkat signifikansinya $0.000<0.05$. Hal ini bearti bahwa terdapat pengaruh signifikan secara bersamasama antara semua variabel bebas terhadap variabel terikat. Sehingga, dapat disimpulkan bahwa model ini layak untuk di uji.

\section{Uji Hipotesis (t-test)}

Uji t statistik (t-test) bertujuan untuk mengetahui hubungan yang signifikan dari masingmasing variabel bebas terhadap variabel terikatnya. Pengujian hipotesis secara parsial dilakukan dengan cara membandingkan nilai $t_{\text {hitung }}$ dengan nilai $t_{\text {tabel. Nilai }} t_{\text {tabel }}$ adalah $\alpha=0,05$ dengan derajat bebas $(\mathrm{db})=\mathrm{n}-\mathrm{k}=277-4=273$ adalah 1,96, berdasarkan hasil analisis pada tabel 4.10 maka dapat diketahui pengaruh variabel independen secara parsial terhadap variabel dependen adalah sebagai berikut. 


\section{Hipotesis 1}

Pengujian hipotesis dilakukan dengan membandingkan $t_{\text {hitung }}$ dengan nilai $t_{\text {tabel }}$. Hipotesis diterima jika $t_{\text {hitung }}>\mathrm{t}_{\text {tabel }}$ atau nilai sig $<0,05$. Nilai $\mathrm{tt}_{\text {abel }}$ pada $\alpha=0,05$ adalah 1,96 . Variabel komitmen profesional nilai thitung adalah 5.547 dan nilai sig adalah 0.000. Dengan demikian dapat dikatakan bahwa $t_{\text {hitung }}>t_{\text {tabel }}$ yaitu 5.546>1.96 atau nilai signifikasi $0,000<0,05$. Nilai koefisien $\beta$ dari variabel komitmen profesional bernilai positif yaitu 6.024. Hal ini menunjukkan bahwa penelitian ini membuktikan komitmen profesional berpengaruh terhadap Whistleblowing, dengan demikian hipotesis pertama $\left(\mathrm{H}_{1}\right)$ diterima.

\section{Hipotesis 2}

Pengujian hipotesis dilakukan dengan membandingkan $t_{\text {hitung }}$ dengan nilai $t_{\text {tabel. }}$. Hipotesis diterima jika thitung $>t_{\text {tabel }}$ atau nilai sig $<0,05$. Nilai $t_{\text {abel }}$ pada $\alpha=0,05$ adalah 1,96 . Variabel sosialisasi antisipatif nilai thitung adalah -3.169 dan nilai sig adalah 0,002. Dengan demikian dapat dikatakan bahwa $t_{\text {hitung }}<t_{\text {tabel }}$ yaitu $-3.169<1,96$ atau nilai signifikasi $0,004<0,05$. Nilai koefisien $\beta$ dari variabel komitmen profesional bernilai negatif yaitu -2.036. Hal ini menunjukkan bahwa penelitian ini membuktikan sosialisasi antisipatif berpengaruh negatif signifikan terhadap Whistleblowing. Dengan demikian hipotesis kedua $\left(\mathrm{H}_{2}\right)$ ditolak

\section{Hipotesis 3}

Pengujian hipotesis dilakukan dengan membandingkan $t_{\text {hitung }}$ dengan nilai $t_{\text {tabel. }}$. Hipotesis diterima jika thitung $>t_{\text {tabel }}$ atau nilai sig. $<0,05$. Nilai $t_{\text {abel }}$ pada $\alpha=0,05$ adalah 1,96. Variabel interaksi 1 $\left(\mathrm{X}_{1} * \mathrm{X}_{3}\right)$ nilai thitung adalah -4.719 dan nilai sig. adalah 0.000 . Dengan demikian dapat dikatakan bahwa $t_{\text {hitung }}<t_{\text {tabel }}$ yaitu $-4.719>1,96$ atau nilai signifikasi $0.000<0,05$. Nilai koefisien $\beta$ dari variabel interaksi $1\left(\mathrm{X}_{1} * \mathrm{X}_{3}\right)$ bernilai negatif yaitu -0.063 . Hal ini menunjukkan bahwa penelitian ini dapat membuktikan religiusitas memperlemah hubungan komitmen profesional terhadap Whistleblowing, dengan demikian hipotesis ketiga $\left(\mathrm{H}_{3}\right)$ ditolak.

\section{Hipotesis 4}

Pengujian hipotesis dilakukan dengan membandingkan $t_{\text {hitung }}$ dengan nilai $t_{\text {tabel. }}$ Hipotesis diterima jika $t_{\text {hitung }}>\mathrm{t}_{\text {tabel }}$ atau nilai sig. $<0,05$. Nilai $\mathrm{tt}_{\text {abel }}$ pada $\alpha=0,05$ adalah 1,96 . Variabel interaksi 2 $\left(\mathrm{X}_{2} * \mathrm{X}_{3}\right)$ nilai thitung adalah 3.189 dan nilai sig. adalah 0.002 . Dengan demikian dapat dikatakan bahwa $t_{\text {hitung }}>\mathrm{t}_{\text {tabel }}$ yaitu $3.189>1,97$ atau nilai signifikasi $0,002<0,05$. Nilai koefisien $\beta$ dari variabel interaksi $2\left(\mathrm{X}_{2} * \mathrm{X}_{3}\right)$ bernilai positif yaitu 0.025 . Hal ini menunjukkan bahwa penelitian ini dapat membuktikan religiusitas memoderasi hubungan positif sosialisasi antisipatif terhadap Whistleblowing, dengan demikian hipotesis keempat $\left(\mathrm{H}_{4}\right)$ diterima.

\section{HASIL DAN PEMBAHASAN \\ Pengaruh Komitmen Profesional terhadap Whistleblowing}

Berdasarkan hasil uji hipotesis pertama, menunjukkan bahwa variabel komitmen profesional berpengaruh terhadap niat whistleblowing. Hal ini ditunjukkan oleh koefisien regresi $\mathrm{X}_{1}$ sebesar 6,024 dengan signifikansi sebesar 0,000 lebih kecil dari 0,05. Dapat diartikan bahwa jika tingkat komitmen professional mahasiswa tinggi maka niat melakukan tindakan whistleblowing akan tinggi pula, begitu sebaliknya jika tingkat komitmen profesional mahasiswa rendah maka akan menurunkan bahkan mengurungkan niat mereka untuk melakukan tindakan whistleblowing.

Penelitian ini sejalan dengan penelitian yang dilakukan oleh Elias (2008) yang menyatakan bahwa komitmen professional mahasiswa akuntansi akan berpengaruh positif terhadap niat 
mahasiswa tersebut melakukan whistleblowing. Mahasiswa dengan komitmen profesional tinggi akan cenderung mempunyai rasa tanggungjawab terhadap organisasinya sehingga akan melakukan upaya untuk menyelamatkan organisasinya apabila terjadi kesalahan yaitu dengan melakukan tindakan whistleblowing.

Komitmen profesional merupakan suatu kesetiaan yang ditumbuhkan dalam diri seorang individu pada profesinya, dimana terdapat didalamnya sesuatu yang dipercayainya, sesuatu yang dapat diterimanya, tujuannya dan nilai-nilai dari suatu profesinya. Komitmen yang ditamankan oleh mahasiswa pada profesinya sebagai mahasiswa dapat dikatakan sangat baik. Apabila melihat seseorang melakukan tindak kecurangan, maka ia tanpa ragu akan segera melaporkan tindakan tersebut (whistleblowing).

\section{Pengaruh Sosialisasi Antisipatif terhadap Whistleblowing}

Berdasarkan hasil uji hipotesis kedua, menunjukkan bahwa variabel sosialisasi antisipatif berpengaruh negative terhadap niat whistleblowing. Hal ini ditunjukkan oleh koefisien regresi $\mathrm{X}_{2}$ sebesar -2,036 dengan signifikansi sebesar 0,002 lebih kecil dari 0,05. Hal ini dapat diartikan bahwa semakin tinggi tingkat sosialisasi antisipatif maka akan menurunkan niat melakukan tindakan whistleblowing, begitu pula sebaliknya. Hasil penelitian ini tidak sejalan dengan penelitian yang dilakukan oleh Elias (2008) yang mengungkapkan bahwa seseorang dengan sosialisasi antisipatif yang tinggi mempunyai kecenderungan dalam melakukan tindakan whistleblowing dibandingkan dengan seseorang dengan sosialisasi antisipatif yang rendah.

Mengindikasikan proses penyampaian ilmu pengetahuan kepada responden saat masih mejalani pendidikan berjalan dengan cukup baik. Hasil penilitian dari variabel sosialisasi antisipatif yang tinggi menunjukkan bahwa responden memiliki pemahaman yang cukup baik terhadap pentingnya pelaporan keuangan (Merdikawati \& Prastiwi, 2012). Kaitannya dengan niat whistleblowing yaitu responden penelitian cukup memahami betapa pentingnya melakukan tindakan whistleblowing jika menemukan suatu tindak kecurangan. Namun, akibat lingkungan yang tidak mendukung berjalannya tindakan whistleblowing membuat para whistleblower berfikir dua kali dalam melakukannya demi menjamin kelangsungan masa kerjanya dan keselamatan hidupnya.

\section{Pengaruh Komitmen Profesional terhadap Whistleblowing melalui Religiusitas sebagai Variabel Moderasi}

Berdasarkan hipotesis ketiga, menunjukkan bahwa religiusitas memperlemah hubungan antara Komitmen Profesional terhadap Niat Whistleblowing. Hal ini ditunjukkan dengan nilai koesofisien $\mathrm{X}_{1} * \mathrm{X}_{3}$ bernilai positif sebesar -0,063 dengan signifikansi sebesar 0,000 lebih kecil dari 0,05. Hasil penelitian ini sejalan dengan Khasif (2017) yang mengungkapkan religiusitas tidak mampu memperkuat hubungan sikap terhadap perilaku (komitmen professional) terhadap niat berperilaku etis (niat whistleblowing).

Pengaruh komitmen professional terhadap niat whistleblowing diperlemah dengan adanya religiusitas. Hood et al. (2009) dan Walker (2012) menjelaskan bahwa religiusitas sepeti roller coster yang dapat naik dan turun pada titik-titik tertentu. Perilaku religius ini tidak jauh dari dua faktor penting yang memengaruhinya yaitu individual dan situasional. Faktor individual itu terdiri dari jangka masa kerja, berapa usia, psikhis, kondisi fisik, jenis kelamin dan apa motivasi berperilaku. Faktor situasional atau biasa disebut lingkungan luar yaitu kondisi kerja, lingkungan kerja dan lainnya (Irma, 2012). 
Religiusitas pada sikap etis (niat whistleblowing) bersifat situasional. "Peran agama itu paradoks; itu membuat prasangka, dan itu melemahkan prasangka". Ketika seseorang dihadapkan pada situasi yang terdesak atau tertekan dapat melemahkan tingkat religiusitas yang dimiliki seseorang (Rashid dan Ibrahim, 2008). Oleh sebab itu, religiusitas belum mampu memperkuat hubungan antara komitmen professional terhadap niat whistleblowing yang dimiliki oleh seseorang.

\section{Pengaruh Sosialisasi Antisipatif terhadap Whistleblowing melalui Religiusitas sebagai Variabel Moderasi}

Berdasarkan hipotesis keempat, menunjukkan bahwa religiusitas memperkuat hubungan antara sosialisasi antisipatif terhadap niat whistleblowing. Hal ini ditunjukkan dengan nilai koesofisien $\mathrm{X}_{2} * \mathrm{X}_{3}$ bernilai positif sebesar 0,025 dengan signifikansi sebesar 0,002 yang lebih kecil dari 0,05. Oleh sebab itu, semakin tingggi religisuistas yang dimiliki seseorang mampu meningkatkan sosialisasi antisipatifnya, sehingga mampu meningkatkan niatnya untuk melakukan whistleblowing.

Keyakinan agama yang tinggi tentunya dapat mencegah orang melakukan tindakan tidak etis dengan adanya rasa bersalah apabila melanggar ajaran agama (Grasmick, Bursik dan Cochran, 1991). Hasil penelitian ini konsisten dengan penelitian yang dilakukan oleh Khasif (2017) yang menjelaskan bahwa religiusitas memoderasi pengaruh norma subyektif (sosialisasi antisipatif) terhadap niat whistleblowing. Meskipun dengan lingkungan yang kurang mendukung terlaksananya perilaku whistleblowing, namu dengan keyakinan agama yang tinggi membuat whistleblower tidak ragu untuk melakukan tindakan tersebut.

\section{SIMPULAN, KETERBATASAN DAN SARAN \\ Kesimpulan}

Penelitian ini bertujuan untuk melihat apakah komitmen profesional dan sosialisasi antisipatif berpengaruh terhadap niat whistleblowing dengan religiusitas sebagai variabel moderasi studi empiris pada mahasiswa akuntansi kota Padang. Berdasarkan hasil penelitian dan pengujian hipotesis yang telah dilaksanakan, maka hasil penelitian dapat disimpulkan bahwa:

1. Komitmen profesional berpengaruh terhadap niat whistleblowing. Hal ini menunjukkan bahwa komitmen profesional yang dimiliki seseorang memengaruhi mereka untuk melaporkan tindak kecurangan (niat whistleblowing).

2. Sosialisasi antisipatif berpengaruh negatif siginifikan terhadap niat whistleblowing. Hal ini menunjukkan bahwa semakin tinggi sosialisasi antisipatif seseorang maka akan semakin rendah keinginan mereka untuk melaporkan tindak kecurangan (niat whistleblowing).

3. Religiusitas memperlemah hubungan komitmen profesional terhadap niat whistleblowing.

4. Interaksi sosialisasi antisipatif yang dimoderasi oleh religiusitas memperkuat pengaruhnya terhadap niat whistleblowing. Hal ini menunjukkan bahwa semakin tinggi religusitas seseorang akan mampu meningkatkan keinginan seseorang untuk melaporkan tindak kecurangan (niat whistleblowing).

\section{Keternatasan}

Meskipun peneliti telah berusaha merancang dan mengembangkan penelitian sedemikian rupa, namun masih terdapat beberapa keterbatasan dalam penelitian yaitu:

1. Dalam penelitian ini hanya menggunakan 3 variabel saja, sehingga cakupannya kurang luas untuk menilai sejauh mana niat seseorang melakukan whistleblowing. 
2. Sampel dalam penelitian ini adalah mahasiswa akuntansi yang belum memiliki pengalaman bekerja dan juga hanya mahasiswa se-kota Padang.

\section{Saran}

Berdasarkan kesimpulan dari hasil penelitian yang telah dijelaskan diatas dapat diberikan saran sebagai berikut:

1. Untuk peneliti selanjutnya agar menambahkan atau menggunakan variabel lain yang mungkin berpengaruh terhadap tindakan whistleblowing seperti saluran pelaporan, dilema etika, dan metode reward dalam melakukan penelitian mengenai whistleblowing.

2. Untuk peneliti selanjutnya dapat menggunakan variabel moderasi lain yang berpengaruh terhadap niat whistleblowing seperti locus of control.

3. Untuk peneliti selanjutnya sebaiknya menggunakan sampel penelitian selain mahasiswa seperti auditor KAP, auditor pemerintah, atau pegawai perusahaan swasta maupun pemerintah.

\section{DAFTAR PUSTAKA}

Amir. (2011). Adat Minangkabau : Pola dan Tujuan Hidup Orang Minang. Jakarta: Citra Harta Prima.

Ancok, D., \& Suroso, F. N. (2001). Psikologi Islami. Yogyakarta: Pustaka Pelajar.

Ancok, J., \& Fuad, A. S. (2005). Psikologi Islam : Solusi Islam Atas Problem Problem Psikologi. Yogyakarta: Pustaka Pelajar.

Alleyne, P., M, H., \& Pike, R. (2012). Towards a Conceptual Model of Whistle-blowing Intention Among External Auditors. The British Accounting Review, 10 - 23.

Amir. (2011). Adat Minangkabau : Pola dan Tujuan Hidup Orang Minang. Jakarta: Citra Harta Prima.

Bagustianto, R. (2014). Faktor-Faktor Yang Mempengaruhi Minat PNS Untuk Melakukan Tindakan Whistle-Blowing (Studi Pada PNS BPK RI). Ekonomi dan Keuangan, 276-295.

Clikeman, P., \& Henning, S. (2000). The socialization of undergraduate accounting students. Issues in Accounting Education, 15 (1): 1-9.

Dwyer, P., Welker, R., \& Friedberg, A. (2000). A research note concerning the dimensionality of the professional commitment scale. Behavioral Research in Accounting, 12: 279-96.

Elias, R. (2008). Auditing studentse professional commitment and anticipatory socialization and their relationship to whistleblowing. Managerial Auditing Journal, 283-294.

Fauzan, Alfi, H., \& Sumiyati. (2014). Pengaruh Komitmen Organisasi Terhadap Kinerja Karyawan PT. Bank Mandiri Tbk. Area Cirebon (Yos Sudarso). Manajemen dan Kewirausahaan.

Ghozali, I. (2013). Aplikasi Analisis Multivariate dengan program IBM SPSS 21 Update PLS Regresi Edisi 7. Semarang: Badan Penerbit Universitas Diponegoro.

Jogiyanto. (2007). Sistem Informasi Keperilakuan. Yogyakarta: ANDI.

Kashif, M., Zarkada, A., \& Thurasamy, R. (2017). The moderating effect of religiosity on ethical behavioural intentions: An application of the extended theory of planned behaviour to Pakistani bank employees. 46 (2): 429-448.

Malik, R. (2010). Analisis Perbedaan Komitmen Profesional dan Sosialisasi Antisipatif mahasiswa PPA dan Non-PPA pada Hubungannya dengan Whistleblowing. Skripsi. Universitas Diponegoro. 
Merdikawati, R., \& Prastiwi, A. (2012). Hubungan komitmen profesi dan sosialisasi antisipatif mahasiswa akuntansi dengan niat whistleblowing. Diponegoro Journal of Accounting, 1, $1-12$.

Rahmaningtyas, D. H. (2008). PerbedPersepsi Mahasiswa PPA dan Non-PPA mengenai penerimaan Etika terhadap Creative Accounting. Skripsi. Universitas Diponegoro.

Rani, K. D. (2009). Analisis Hubungan Komitmen Profesional dan Antisipatori Dini Mahasiswa Akuntansi dan Hubungannya dengan Pelaporan Pelanggaran. Skripsi. Universitas Diponegoro.

Riduwan. (2011). Dasar-dasar Statiska Bandung. Bandung: Alfabeta.

Roundy, P. (2009). Work and Religion: Artificial Dichotomy or Competing Interests? International Journal of Human and Social Sciences, 311-317.

Schultz, J., Johnson, D., Morris, D., \& Dyrnes, S. (1993). An investigation the reporting of questionable acts in an international setting. Journal of Accounting Research, 31(1): 75103.

Semendawai, A. H., \& dkk. (2011). Memahami whistleblower. Jakarta: Lembaga Perlindungan Saksi dan Korban (LPSK). Retrieved from www.lpsk.go.id.

Shabbir, M. (2007). Factors affecting decision styles: an empirical study of Pakistani managers. Tesis. University of Malaya.

Shah Alam, S., Mohd, R., \& Hisham, B. (2011). Is religiosity an important determinant on Muslim consumer behaviour in Malaysia? Journal of Islamic Marketing, 2(21): 83-96.

Sugiyono. (2008). Metode Penelitian Kuantitatif Kualitatif dan R\&D. Bandung: Alfabeta.

Sulistomo, A., \& Prastiwi, A. (2012). Persepsi mahasiswa akuntansi terhadap pengungkapan kecurangan. 1-28. 